Journal of Educational Social Studies
JESS $9(2)(2020): 20-26$
UNNES
http://journal.unnes.ac.id/sju/index.php/jess

\title{
Implementation of Multicultural Values in Diversity of a Multiethnic School (A Case Study: Kuncup Melati Junior High School, Semarang)
}

\author{
Ika Rizqiyawati ${ }^{1 凶}$, Rusdarti Rusdarti ${ }^{2}$, Suwito Eko Pramono ${ }^{2}$ \\ ${ }^{1}$ PKBM Anugrah Bangsa Semarang, \\ ${ }^{2}$ Universitas Negeri Semarang, Indonesia.
}

\begin{tabular}{l} 
Article Info \\
\hline History Articles \\
Received: \\
5 September 2020 \\
Accepted: \\
3 November 2020 \\
Published : \\
17 December 2020 \\
\hline Keywords: \\
Chinese ethnic group; \\
Javanese ethnic group; \\
Multicultural education; \\
Multicultural values; \\
symbolic interactionism
\end{tabular}

\begin{abstract}
Kuncup Melati Junior High School (JHS) is a multiethnic school whose students come from Chinese and Javanese ethnic groups. Both groups have a negative stereotype towards one another and often engage in conflicts. The school opens a room for discussion for both groups, proving that both can coexist in diversity. This study aims to analyze the symbolic interactionism and the implementation of multicultural values. Data analysis technique used were qualitative technique, borrowing the symbolic interactionism theory of Herbert Blumer. The informants were the teachers, the Chinese students, and Javanese students. The data collection technique employed in-depth interview, observation, and documentation study. The results revealed that the symbolic interactionism between two groups can be interpreted from multiethnic friendship and understanding of each other's culture and religion. This can reduce the stereotype between two groups, and in turn, result in respect from one another. The heterogeneous school environment showcasing the implementation of respect for one another is indirectly internalized in students' behavior. Multicultural values found in Kuncup Melati JHS are tolerance, solidarity, and equality. This study recommends to open a more diverse multietchnic and multifaith interaction because multicultural values cannot only be taught in class, but rather have to be experienced personally.
\end{abstract}

\footnotetext{
Correspondence address:

Pedalangan, Kec. Banyumanik, Kota Semarang, Jawa Tengah

E-mail: ikarizqiya20@gmail.com
} 


\section{INTRODUCTION}

Indonesia is a multicultural country consisting of various ethnicities, races, religions, and culture. According to Pettalogi (2013: 173174), the diversity of Indonesia is visible through its socio-cultural and geographical aspects. Firstly, vertical pluralism is reflected in the social structure with social stratification. Secondly, horizontal pluralism is illustrated in social units based on the differences in ethnicity, religion, and custom. Diversity is like a two edged knife as it can be a gift to a nation as well as a conlifct maker. One interethnic relationship that still creates prejudice is between Chinese and Javanese.

The relationship between the minority (Chinese) and the majority (Javanese) is still often tarnished with stereotype against one another. The Chinese is seen as "foreigner" or "immigrant" although they have existed among the different generations in Indonesia since long time ago. Chinese ethnic group is considered as Peranakan (gererally refers to people of mixed Chinese and Malay/Indoneian heritage) in Indonesia (Copel, 2003: 15). Their existence still receives racial stereotype and anti-China sentiment (Gayatri, et al. 2019:2). On the other hand, Javenese is deemed as "the local or "the house owner." This social construction results from the government policy of new order which heightened the stereotype against the Chinese (Gayatri, et al. 2019:2). According to Freedman (2010:440), the New Order government categorized the people into the local and the foreigner, and Chinese that falls into the foreigner category (minority) were forced to assimilate by dismissing their Chinese identity. This sparked a gap between the ethnic groups, affecting the interaction pattern between the two ethnic groups. The interaction between the two ethnics often turns into a conflict when both do not have the same goal (Wirutomo, et al. 2012: 113). To reduce prejudice, a room for interaction between the two is needed.

Interaction supported by heterogenous environment can serve as a tool to instill multicultural values. Multicultural values are a process of receiving and appreciating cultural or religion diversity in order to create peace and unity among different human beings. According to $\mathrm{Au}$, Gorski, Nieto \& Bode (in Shannon \& Baker, 2018:48) that multicultural represents a set of principles, values, and practices directly associated with social justice. It encompasses a resolve to inequality, stereotype, and discrimination where it has to provide social justice for all students (Kim, 2020: 89). According to James Banks (2002:3), multicultural eeducation is an education which explores differences so that students are able to respond to differences with tolerance. In line with the argumentation of Parekh (2008:322), multiculturalism is a tenet that considers differences or diversities as equally same, deserving the same respect and acceptance. UNESCO mentions: "Multicultural education uses learning about other cultures in order to produce acceptance or at least tolerance, of these cultures. Intercultural Education aims to go beyond passive coexistence, to achieve a developing and sustainable way of living together in multicultural societies through the creation of understanding of, respect for and dialogue between the different cultural group (Sleeter, 2018: 17).

Educational institutions play a strategic function to instill multicultural values. At a time where everything is interconnected, the installment of multicultural become an essential matter in education realm (Ishmuradova, I.I. \& Ishmuradova, A.M: 111). Indonesia's national motto "Unity in Diversity" has brought diversities into one, yet it has not been fully rationalized in education (Raihani, 2018:993). The school text books circulating around still invoke stereotype against another culture (Nakaya, 2018:133). The finding of Endang Turmudi's study, senior researcher at Indonesian Institute of Sciences (2017), uncovered that $21 \%$ students and $21 \%$ teachers stated that Pancasila is no longer relevant as the national principle of Indonesia. A more ironic fact is that the data show $52.3 \%$ students agree with violence for the sake of religion solidarity and $14.2 \%$ justify the bombings done by radical 
groups. Schools, which are expected to shape the characters of the students to become wellmannered citizens, are surprisingly found to conduct education that backlash the basis principles of education. Therefore, a multicultural school is necessary to build a culture based on discipline, accountability, tolerance, peace, and social awareness (Sutarmi, Raharjo, \& Pramono, 2016: 142).

An open interethnic interaction can give a new point of view of another culture, so it can reduce stereotype and conflict. The interaction made creates some interpretations to someone who is engaging in it. According to Blumer (Ritzer \& Smart, 2015:429), symbolic interactionismism rests on three premises as follows: "First, human beings act towards things on the basis of the meanings those things have for them. Second, the meanings of things derive from social interaction. Third, these meanings are dependednt on, and modified by, an interpretive process of the people who interact with one another".

Interaction is dynamic and fluid to the social condition of humans. Humans use symbols to represent what they mean when interacting with their counterparts. Interaction and communication form culture.

In Semarang, Chinese and Javanese live with one another in the midst of diversity. This occurs due to the fact that Chinese and Javanese in Semarang have the same social position and are the cultural hosts (Kholiludin, 2019:116). A good example to this is Kuncup Melati JHS. It is a school with predominant Chinese culture whose the majority of students from Javanese ethnic group.

Based on the previous explanation, the writer saw an importance to conduct a study on the symbolic interactionism between the Chinese and Javanese students and the implementation of multicultural values in the education process at Kuncup Melati JHS. This study aimed to analyze the symbolic interactionism and the implementation of multicultural values at the school. Notwithstanding, further studies on other examples of the implementation of multicultural education with various approaches are necessary to complement. This study is hoped to become an example of multicultural education implementation; consequently, more multi-ethnic interaction rooms are open and multicultural values do not end up just as a theory but a personal experience.

\section{METHODS}

The method used in this research was the qualitative one with a case study approach. This was used to describe in depth the symbolic interaction between Chinese and Javanese ethnic students and the implementation of multicultural values at Kuncup Melati JHS. Kuncup Melati JHS is a sample school that implements multicultural education by opening up spaces for interaction between Chinese and Javanese ethnic students. Data collection techniques were carried out through interviews, observation, and documentation. The informants interviewed were the main informants: students of Chinese and Javanese ethnicities, supporting informants: school principals, social studies teachers, extracurricular trainers.

This study used triangulation to test data validation. Firstly, source triangulation compared the sources of information from one source to another. Secondly, theoretical triangulation prepared interview and collection guidelines in accordance with Herbert Blumer's concept and theory of symbolic interactionism. Thirdly, structural triangulation collected data that are in accordance with the research. The data analysis technique used was in accordance with the stages of Miles and Huberman.

\section{RESULTS AND DISCUSSION}

\section{Symbolic interactionism at Kuncup Melati JHS as a Multiethnic School}

Kuncup Melati JHS is a school with Chinese culture, under the management of the Khong Kauw Hwee Foundation. The purpose of the establishment was to curtail the dropout rate by giving full tuition fee waiver (free schools) to underprivileged people. Even though the school 
is embedded with Chinese culture, this school is open to all ethnicities and religions without discrimination. Teachers and students come from different ethnicities and religions so as to create a heterogeneous social environment. According to the Principal of Kuncup Melati JHS, Mrs. Amitra explained that $80 \%$ of students came from Javanese ethnicity and 20\% of Chinese ethnicity (mixed).

The symbolic interactionism between Chinese and Javanese is forged through friendship, religion and cultural celebrations. Friendship becomes a means to get to know each other and understand differences. Play has an important role in the physical, psychological, and social development of children (Sari, Raharjo, \& Utomo, 2017: 136). When forging friendship, students of Kuncup Melati JHS befriend with one another regardless differences in religion and ethnicity. The diverse social environment in the school trains the students to be tolerant and respectful towards one another, so there is no room for stereotype against others of different religion or ethnicity to grow. This type of environment in the school provides an opportunity for its students to get to know others of different ethnicity, which indirectly plays a role in instilling multicultural values.

The hererogenous school environment supports the cultivation of multicultural values. The multicultural values, which are lectured in class, can be applied when interacting with one another. The use of the same languages, Indonesian and Javanese, as the languages of instruction gives the students a sense of similarity. Although some students are from Chinese descent, they cannot speak Mandarin or Hokkian. The similarity in the language of instruction breaks the communication barrier between the students of different ethnic groups, invoking a sense of similarity and equality. The use of the same language glues them together.

The open and fused friendship between Chinese and Javanese is inseparable from family environment and community. Family is the smallest social institution that is most effective in instilling values (Kusumaningtyas, Atmaja, \& Subagyo, 2019: 21). The parenting style applied by parents indirectly creates an enculturation process in their children, which from childhood is embedded so that it is internalized in them, and later they try to adjust to the environment in which they are living (Marlin \& Rusdarti, 2016: 151-152). Meanwhile, community plays a role in maintaining social order (Sumihudiningsih, Soesilowati, \& Atmaja, 2019: 212). These two things are interrelated and complementary for each other in instilling multicultural values. The diversity that exists in Semarang with rare ethnic and religious conflicts makes the community, including its youths, to be tolerant and respectful to differences.

Kuncup Melati JHS has a range of extracurricular activities, for example: Barongsai (lion dance), Javanese traditional dance, Saffel Dance, computer, culinary, scout, and modern dance. Extracurricular activities can develop cognitive, psychomotor, and affective domains of a student. An array of extracurricular activities becomes the platform to develop talents, instill values, and introduce modern, traditional or multiethnic culture to students. Every student can join all extracurricular activities regardless their ethnicities. Kuncul Melati JHS often showcases Barongsai performance to public. On Chinese New Year (CNY), all people in the school take part in the performance from its preparation to performance day. Decorating CNY ornaments like lantern and arranging basket cake are done hand in hand by teachers and students. On CNY, everyone at school gets a basket cake.

During Ramadhan (Muslim Holy Month), a breaking-of-the-fast gathering is held. Every student prays based on their belief. Kuncup Melati JHS provides prayer tools for the students who pray. On Friday, the male students are allowed to be dismissed to perform Friday prayer in the middle of the class. Muslim teachers are permitted to wear headscarf.

Symbolic interactionism creates an interaction room between two ethnic groups to get to know one another and understand differences. An example demonstrated by the school and all teachers plays a part in the construction of the students' characters in seeing 
differences. According to Debbag \& Fidan (2020: 118), an example shown by teacher has a positive impact on the cultivation of multicultural values in students. Direct experiences by students when interacting and a role model from the surrounding inculcates multicultural values in both ethnic groups that can reduce negative stereotype and conflicts.

\section{Implementation of Multicultural Values at Kuncup Melati JHS}

The diversity of ethnic and religious differences is not an obstacle in establishing interactions. There are three multicultural values applied by Kuncup Melati JHS: tolerance. solidarity, and equality. Firstly, tolerance is an attitude that respects differences even though it contradicts one's own point of view, beliefs, habits, and behavior. However, that does not mean sacrificing the beliefs or principles they adhere to (Muzayanah, 2017: 227). The tolerance practice carried out by Kuncup Melati JHS is respect for the worship of other religions. Every Friday, male students who are Muslims are allowed to carry out their Friday prayer obligation, and even Kuncup Melati JHS provides their prayer tools. During the month of Ramadan, a joint breaking fast event is held. Muslim female teachers are allowed to wear a headscarf. During the Chinese New Year celebration, the school holds a basket cake distribution event where all students and teachers get a basket cake. Although the majority are from Javanese ethnicity, during the celebration of Chinese culture, all parties are involved, starting from decorating Chinese New Year ornaments, packing basket cakes, and performing Barongsai.

Secondly, solidarity is a form of internal unity strength in a group, which is adhered to together by brotherly ties or regional ties. Some forms of solidarity manifest in communal activities such as eating together, cooking together, sharing learning resources, providing drinking water for common interests, visiting friends who are sick. Parents have their schedules to take turn to cook at school with the ingredients that have been provided by the school. The meals are provided for lunch to children before extracurricular activities. Not all students at Kuncup Melati JHS have cellphones. When there are assignments that require searching for information on the internet, students who have cellphones share learning resources with others who do not have one. Provision of communal drinking water is done in order to save money and also reduce the use of drinking water plastic. The students in each class collect their money; one of the allocations is to buy drinking water. Students bring their own drinking bottles, then refill them when they want to drink. When there are friends who are sick or experience misfortunes, they show support to each other.

Thirdly, equality is a concept that recognizes a group of people or communities of different cultures deserving the same respect and appreciation. Parekh (2008: 322) called multiculturalism as the notion of "equality in difference or equality in diversity". Kuncup Melati JHS with Chinese ethnic background accepts all underprivileged students from various ethnicities and religions. Even though Kuncup Melati JHS is known as a free school, the teaching and facilities provided to its students are very much considered; for instance, every classroom is facilitated with projectors, fans, CCTV. The school treats its students equally according to the rights and obligations of students. Equality values are also implemented in extracurricular activities. Kuncup Melati JHS with its strong Chinese culture continues to hold extracurricular activities for traditional Javanese dance. This states that Kuncup Melati JHS does not prohibit students from knowing or studying other cultures. In fact, the existence of Javanese traditional dance as an extracurricular activity at Kuncup Melati JHS exemplifies an example of openness towards other cultures. All students have the same opportunity to participate in all activities according to their abilities.

The results of the study indicated that if a person is placed in a heterogeneous environment with intense interaction outside his group, it can reduce prejudice against other groups. An environment that exemplifies multicultural 
values provides its own meaning for students in interacting with other people. Thus, multicultural values such as tolerance, solidarity, and equality are indirectly internalized in students. This converges with Herbert Blumer's theory of symbolic interactionism which states that humans act based on meaning. The meaning stems from the social interactions that have been experienced and have shaped their own behavior.

\section{CONCLUSION}

School plays a strategic role to open an interaction room for differences. The symbolic interactionism at Kuncup Melati JHS is visible through two things. Fistly, the students befriend with one another regardless ethnicity. They use the same language of instruction, eat together and play together. Secondly, they get to know each other's culture through religion rituals and cultural celebrations such as Chinese New Year where they wear $\mathrm{CNY}$ attributes and distribute basket cake or during Ramadhan where they break fast together. This can reduce stereotype between ethnic groups and primordialism. Moreover, the heterogenous school environment allows the real implementation of multicultural values such as tolerance, solidarity, and equality. It indirectly gives meaning to the students and later shapes their characters. This is in line with Herbert Blumer's theory of symbolic interactionism that humans in carrying out their actions are not just solely based on reactions but based on meaning. The harmony in diversity that exists at Kuncup Melati JHS proves that by opening up room for interaction can reduce prejudice, primodialism and in turn create mutual respect. This also implies that diversity can coexist side by side.

\section{REFERENCES}

Ardinastiti, N., Masrukhi., \& Suhandini, P. 2019. The Implementation of Multicultural Values on Vocational High School Students (A Research at Bagimu Negeriku Vocational High School
Semarang). Journal of Educational Social Studies, 8(1): 27-34.

Banks, James A. 2002. An Introction to Multicultural Education. Boston: Allyn and Barcon.

Copel, Charles A. 2003. Kendala-kendala Sejarah dalam Penerimaan Etnis Cina di Indonesia yang Multikultural. Antropologi Indonesia, 71: 13-22

Debbag, M. \& Fidan, M. 2020. Relationships between Prospective Teachers'

Multicultural Education Attitudes and Classroom Management Styles. International Journal of Progressive Education, 16(2). 111-121.

Gayatri, Irine Hiraswari, et al. 2019. Tionghoa dan Keindonesiaan: Komunitas Tionghoa di Semarang dan Medan. Jakarta: Yayasan Pustaka Obor

Freedman, Amy. 2010. Political Institutions and Ethnic Chinese Identity in Indonesia. Asian Ethnicity, 4(3): 439-452

Ishmuradova, I.I. \& Ishmuradova, A.M. 2019. Multicultural Education of Students as an Important Part of Education. International Journal of Higher Education, 8(7):111-115.

Kim, Hyein Amber. 2020. Understanding "Koreanness" Racial Stratification and Colorism in Korea and Implications for Korean Multicultural Education. International Journal of Multicultural Education, 22(1): 76:97

Kholiludin, Tedi. 2019. Pecinan di Pecinan: Santri, Tionghoa, dan Tuan Rumah Kebudayaan Bersama di Kota Semarang. Semarang: Lembaga Studi Sosial dan Agama (eLSA) Press.

Kusumaningtyas, N., Atmaja, H.T., \& Subagyo. 2019. The Role of Social Media, Family, and School in Building Indonesia Value to Multi-Ethnic Students at SMP Negeri 2 Pekalongan. Journal of Educational Social Studies, 8(1): 19-26.

Marlin, M.E., \& Rusdarti. 2016. Konstruksi Sosial Orang Tua tentang Pendidikan dan Pola Asuh Anak Keluarga Nelayan. 
Journal of Educational Social Studies, 5(2): 150-155.

Muzayanah, U. 2017. Indeks Pendidikan Multikultural dan Toleransi Siswa SMA/K di Gunungkidul dan Kulonprogo. Jurnal Penelitian Pendidikan Agama dan Keagamaan, 15(2):223-240.

Nakaya, Ayami. 2018. Overcoming Ethnic Conflict through Multicultural Education: The Case of West Kalimantan, Indonesia. International Journal of Multicultural Education, 20(1): 118-137.

Parekh, Bikhu. 2008. Rethinking Multiculturalism: Cultural Diversity and Political Theory. New York: Palgrave Macmillan.

Pettalogi, S.S. 2013. Islam dan Pendidikan Humanis dalam Resolusi Konflik Sosial. Cakrawala Pendidikan, 2: 172-182.

Raihani. 2018. Education for Multicultural Citizens in Indonesia: Policies and Practices. International Journal of Multicultural Education, 48(6).

Ritzer, George. \& Smart, Barry. 2015. Handbook: Teori Sosial. Jakarta: Nusa Media.

Sari, A.D., Raharjo, T.J., \& Utomo, C.B. 2017. Learning Relevance IPS against Student Social Interaction in Multicultural Scope on Junior High School Remaja Parakan.
Journal of Educational Social Studies, 6(3): 135-142.

Sumihudiningsih, Y., Soesilowati, E., \& Atmaja, H.T. 2019. The Social Behaviors of Marginal Group Adolescents in Semarang. Journal of Educational Social Studies, 8(2): 209-216.

Shannon, P \& Baker. 2018. A Multicultural Education Praxis: Integrating Past and Present, Living Theories, and Practice. International Journal of Multicultural Education, 20(1):48-66.

Sleeter, Christine. 2018. Multicultural Education Past, Present, and Future: Struggles for Dialog and Power-Sharing. International Journal of Multicultural Education, 20(1): 5-20.

Sutarmi, Tri Joko Raharjo \& Suwito Eko Pramono. 2016. Implementasi Pelaksanaan Pendidikan Karakter sebagai Landasan Wawasan Kebangsaan di SMK Negeri 1 Kendal Kabupaten Kendal. Journal of Educational Social Studies, 5(2):136-144

Turmudi, Endang. (2017, Maret 01). Cited on 24th January 2020. Intoleransi di Ruang Kelas.

Wirutomo, Paulus, dkk. 2012. Sistem Sosial Indonesia. Jakarta: Universitas Indonesia Press 